\title{
Spatial and temporal distribution of phytoplankton with emphasis on the harmful and toxic algae in the Limboto Lake
}

\author{
Mitahul Khair Kadim ${ }^{1}$, Femy M. Sahami ${ }^{1}$, Dewi J. Hasiru ${ }^{1}$ \\ ${ }^{1}$ Faculty of Fisheries and Marine Science, Gorontalo State University, Indonesia \\ *Corresponding author: miftahulkhairkadim@ung.ac.id
}

\begin{tabular}{l} 
ARTICLE INFO \\
\hline Keywords: \\
Distribution; Phytoplankton; \\
Harmful and toxic; Limboto \\
Lake \\
How to cite: \\
Kadim, M. K., Sahami, F. \\
M., \& Hasiru, D. J. (2020). \\
Spatial and temporal \\
distribution of \\
phytoplankton with \\
emphasis on the harmful \\
and toxic algae in the \\
Limboto Lake. Tomini \\
Journal of Aquatic Science, \\
1(2), 37-44. \\
\end{tabular}

\begin{abstract}
This study aims to describe Limboto Lake's condition based on the spatial-temporal abundance of phytoplankton and the presence of harmful algae species. Sampling was conducted in February to April 2018 at six stations. The phytoplankton found in Limboto Lake consisted of 7 divisions from 80 species, namely Chlorophyta (35 species), Euglenophyta (17 species), Bacillarophyta (13 species), Cyanophyta (7 species), Cryptophyta (4 species), Dinophyta (3 species) and Chyrosphyta (1 species). The results of phytoplankton distribution in Limboto Lake varied on average among stations as well as observation times. The results show that the average of phytoplankton abundance at station 1 , station 2, station 3 , and station 4 categorized as medium polluted waters with 4,903 ind. L$1,5,000$ ind. $L-1,9,418$ ind. $L-1$, and 10,049 ind. $L-1$, respectively. The abundance at station five is included in the lightly polluted category with an average phytoplankton abundance of 1,541 ind/L, while station 6 is in the heavily polluted category with an average value of 20,894 ind. L-1. Species that can be used as indicator species for pollution are those with the highest abundance value, namely Microcystis sp., which indicates that Limboto Lake contains high nitrate and phosphate.
\end{abstract}

\section{INTRODUCTION}

Limboto Lake is the largest lake in Gorontalo Province that has an essential role in supporting people who live around the area. Limboto Lake activities are capture fisheries, aquaculture, agriculture, and tourism (Ladja et al., 2020). Agricultural activities around Lake Limboto can affect the presence of organisms in the lake, including phytoplankton. This lake is used by the community to support activities.

Phytoplankton is part of the plant group of plankton free to float and drift in the water and can photosynthesize also produce oxygen (Apridayanti, 2008). Certain types of phytoplankton can deteriorate water quality if the amount is excessive (blooming) (Anderson et al., 2008). Several types of phytoplankton can produce toxins that have the potential to cause Harmful 
Algae Blooms (HABs) when their distribution and abundance are in large quantities in water. The phytoplankton types include Alexandrium sp., Gymnodinium sp., Mycrocystis sp., and Peridinium sp. (Mos, 2001).

The distribution of phytoplankton in waters can provide information about water pollution, which can be seen from the composition of a division of plankton organisms in the waters (Sediadi, 2004). The relationship between phytoplankton abundance and water pollution is positive. If the abundance of phytoplankton is high, it also can be said that these waters have high pollution (Sulastri et al., 2008).

Pollution due to the blooming of an organism can occur in Limboto Lake. Observing the organisms that live in these waters is a way to find out this phenomenon. Sahami (2006) reported that Limboto Lake was polluted by organic matter, using gastropods as an indicator. In addition to gastropods, phytoplankton can also be used as an indicator of polluted waters as it is the first organism to take nutrients in the waters. Phytoplankton is very sensitive to environmental changes (Apridayanti, 2008). This study aims to determine Limboto Lake condition based on the spatial-temporal abundance of phytoplankton and the presence of harmful/toxic algae.

\section{MATERIAL AND METHODS}

Study site. Sampling was carried out from February to April 2018 in Limboto Lake, Gorontalo Province. The research location is divided into six stations (Figure 1). Sampling was carried out once per month at each station.

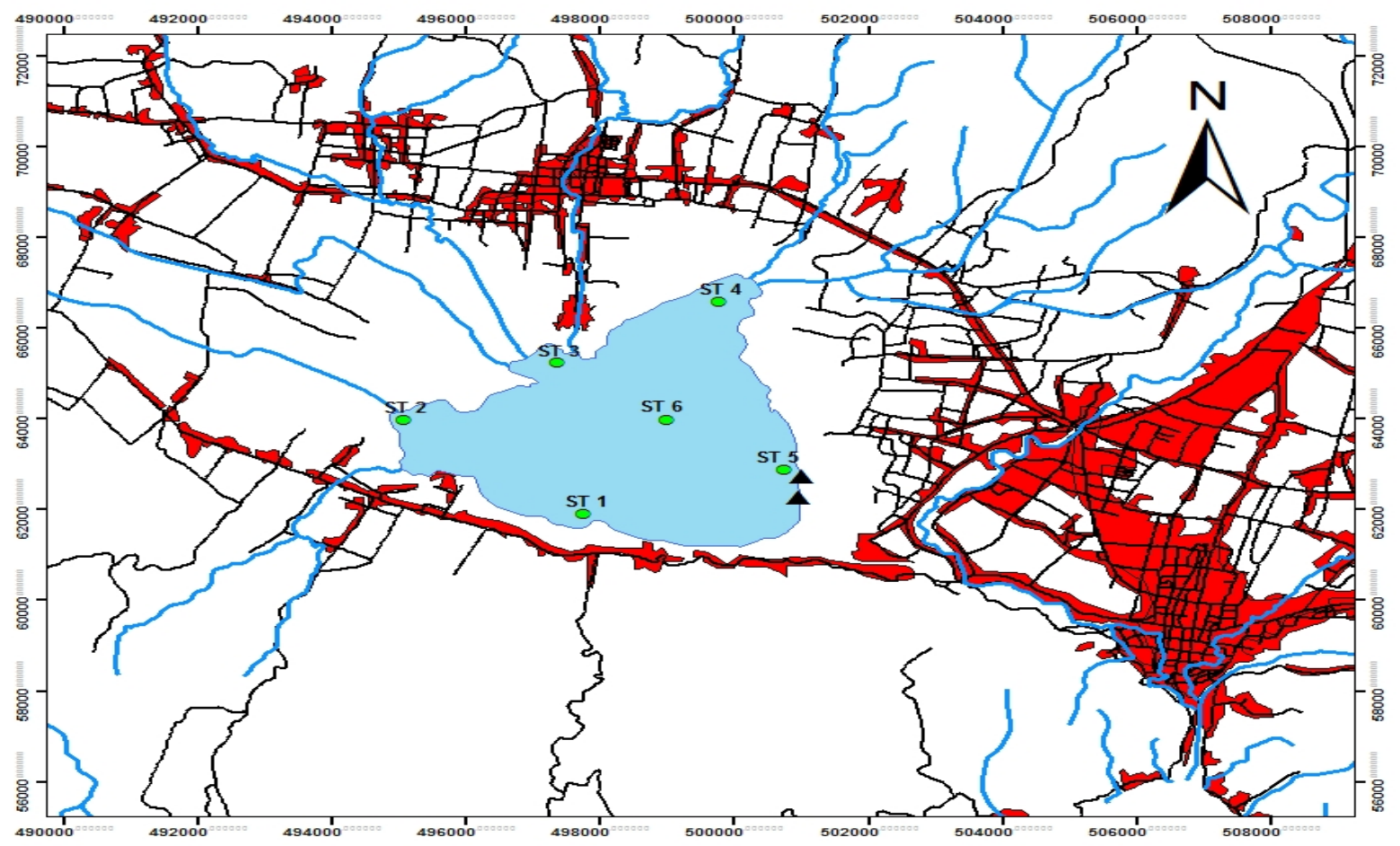

Figure 1. Study area (Limboto Lake). The green dots $(\bullet)$ indicate the coordinate position of the sampling site.

Procedures. The sampling procedure refers to the APHA standard method (Rice et al., 2012). Plankton samples were taken using plankton-net (meshsize $25 \mu \mathrm{m}$ ), then preserved with $1 \%$ Lugol solution. Phytoplankton was identified taxonomically using a light microscope referred to Davis (1955) taxonomical guide. The abundances were measured using SRC, Lackey droptransect method. Biological diversity index $\left(\mathrm{H}^{\prime}\right)$ and dominance index (D) were calculated according to the following equation (Shannon \& Wiener and Sampson index, 1949 in Odum, 
1998). Physical parameters such as temperature, transparency, $\mathrm{pH}$, and dissolved oxygen were conducted in situ in each station. In contrast, nitrate and orthophosphate performed exsitu and determined using spectrophotometry according to the APHA (Rice et al., 2012) methods.

Data analysis. Water quality parameters and the number of phytoplankton species during sampling were performed descriptively.

\section{RESULTS AND DISCUSSION}

Physico-chemical characteristics. The physico-chemical parameter values of Limboto Lake waters during the study can be seen in Table 1.

Table 1. Mean value of water characteristics of Limboto Lake

\begin{tabular}{llcccccc}
\hline \multirow{2}{*}{ No } & \multirow{2}{*}{ Parameters } & \multicolumn{7}{c}{ Stations } \\
\cline { 3 - 7 } & & 1 & 2 & 3 & 4 & 5 & 6 \\
\hline 1 & Temperature $\left({ }^{\circ} \mathrm{C}\right)$ & 31 & 31.9 & 30.8 & 31.1 & 29.3 & 32 \\
2 & Transparency $(\mathrm{cm})$ & 55.2 & 19.9 & 25.8 & 29.5 & 33.2 & 34 \\
3 & pH & 6.5 & 6.4 & 6.8 & 6.6 & 6.3 & 7.0 \\
4 & DO $\left(\mathrm{mg.} \mathrm{L}^{-1}\right)$ & 5 & 5 & 5.6 & 5.2 & 5.6 & 4.7 \\
5 & Nitrate $\left(\mathrm{mg}^{-1}\right)$ & 1.4 & 1.4 & 1.5 & 1.5 & 1.3 & 1.4 \\
6 & Phosphate $\left(\mathrm{mg}^{-1} \mathrm{~L}^{-1}\right)$ & 3.9 & 2.8 & 2.1 & 3.8 & 2.3 & 2.9 \\
\hline
\end{tabular}

The average water surface temperature ranged between 29.3 to $32{ }^{\circ} \mathrm{C}$. Meanwhile, the highest temperature were found in April $\left(32.6^{\circ} \mathrm{C}\right)$. The ideal temperature for phytoplankton growth at 27-30 ${ }^{\circ} \mathrm{C}$ (Boyd et al., 2013). Transparency was ranging from 19.5 to $55.2 \mathrm{~cm}$. During the rainy season in February, the transparency was found in the lowest value $(19.4 \mathrm{~cm})$, and the highest was shown in April (dry season), $46.6 \mathrm{~cm}$.

During the sampling period, the mean values of $\mathrm{pH}$ were never below 6.3. The $\mathrm{pH}$ was recorded between 6.3 and 7 . High pH (alkaline) can limit algae growth and photosynthesis performance (Bergstrom et al., 2007). The mean values of dissolved oxygen concentrations ranged between 4.7-5 mg. $\mathrm{L}^{-1}$. The lowest concentration were found in April. Oxygen concentration in waters are strongly influenced by temperature (Koralay et al., 2018). The decrease in DO will affect algae diversity and biomass (Haas et al., 2014).

During the sampling period, nutrient concentration, nitrate, and phosphate were high in all sampling sites. It is indicated that the waters of Limboto Lake were polluted. Mustofa (2015) reported that when the concentration of nitrate was $>0.5 \mathrm{mg}$. $\mathrm{L}^{-1}$ and the phosphate concentration was $>0.03 \mathrm{mg} . \mathrm{L}^{-1}$, that indicated the waters in heavy polluted.

Phytoplankton abundance. Phytoplankton found in Limboto Lake consist of 80 species and 7 divisions (Figure 4), namely Chlorophyta (35 species), Euglenophyta (17 species), Bacillarophyta (13 species), Cyanophyta (7 species), Cryptophyta (4 species), Diniphyta (3 species), and Chyrosphyta (1 species). The number of species found in Limboto Lake is still higher than the research by Lukman et al. (2008), which only found 37 species in Limboto Lake.

Chlorophyta has the highest number of species found in Lake Limboto, followed by Euglenophyta and Bacillarophyta. At the same time, Cyanophyta is the division with the most number of individuals found. According to Adjie et al. (2017), Chlorophyta is mostly found in freshwater, especially stagnant water, qualitatively and quantitatively. Offem et al. (2013) stated that abundance Chlorophyta is due to its being more tolerant of environtmental stresses and has the ability to reproduce and grow faster than other divisions. Garno (2016) stated that Cyanophyta is one of the phytoplankton divisions that is easily found in freshwater plankton 
communities. Abadi et al. (2014) reported that waters dominated by Cyanophyta is categorized as polluted. It disturbs aquatic life due to the increased toxic content.

Several types of phytoplankton dominate and distribute widely and play an essential role in freshwater, especially lake. The phytoplankton came from the Chlorophyta, Euglenophyta, Bacillarophyta, and Cyanophyta Divisions (Noryadi, 1998 in Sulastri et al., 2008). The average abundance of phytoplankton found during the study varied between 1,541-20,894 ind. $\mathrm{L}^{-1}$ (Table 2). The abundance of phytoplankton can be seen in Table 2.

Table 2. The abundance of phytoplankton (ind. $\mathrm{L}^{-1}$ ) during the study

\begin{tabular}{lcccc}
\hline \multirow{2}{*}{ Stations } & \multicolumn{3}{c}{ Abundance (ind. $\mathrm{L}^{-1}$ ) } & \multirow{2}{*}{ Average } \\
\cline { 2 - 4 } & February & March & April & \\
\hline Station 1 & 2,280 & 4,017 & 5,981 & 4,093 \\
Station 2 & 2,720 & 5,320 & 6,960 & 5,000 \\
Station 3 & 4,680 & 10,127 & 13,449 & 9,418 \\
Station 4 & 2,920 & 12,480 & 14,747 & 10,049 \\
Station 5 & 1,280 & 1,360 & 1,982 & 1,541 \\
Station 6 & 5,280 & 29,800 & 27,601 & 20,894 \\
\hline Avarage & 3,193 & 10,517 & 11,787 & \\
\hline
\end{tabular}

Spatially, station 6 has the highest average abundance $\left(20,894\right.$ ind. $\left.\mathrm{L}^{-1}\right)$, presumably as that location is close to floating net cage activities, which can provide high nutrient input. It is also supported by the highest content of nitrate and phosphate besides station 4. It has the potential to increase the biomass of aquatic plants due to nutrient enrichment. Lehmusluoto (2000) stated that domestic waste pollution is one of the causes of eutrophication in lakes. According to Rahman et al. (2017), one of the eutrophication effects influences phytoplanktons presence in waters. The high concentration of nutrients can be affected by the number of human activities around the waters. Purnamaningtyas \& Tjahjo (2017) explained that the activities that have exceeded the environments carrying capacity could increase organic matter due to leftover feed and fish metabolism. Besides, Zhou et al. (2011) reported that an artificial fish feed is rich in nitrogen and phosphorus. If the feed is not entirely consumed, it will increase nutrients, which can increase water fertility.

Station 5, the Limboto Lake outlet area, has the lowest average abundance $\left(1,541\right.$ ind. $\left.\mathrm{L}^{-1}\right)$. The low abundance value is presumably due to the lower nutrient content in this station than other stations even though the DO value at this station is high. The low phytoplankton population in the outlet area was also shown by the research of Soeprobowati \& Suedy (2010) in Lake Rawa Pening even though it had high productivity. In addition, phytoplankton is thought to have been carried away by the current as of the characteristics of its life, which are strongly influenced by the movement of the current. Apridayanti (2008) states that phytoplankton is part of plankton from plant groups free to float and drift in the water.

The average abundance of phytoplankton in February was the lowest and then continued to increase in March and April. During the research, February was the end of the rainy season and still rained frequently. In contrast, March and April are the beginning of dry season and have a long exposure, allowing phytoplankton to rise to the surface due to phytoplankton positive phototaxis. Thoha (2010) stated that phytoplankton will perform photosynthesis and reproduce well if they are in water conditions exposed to sunlight as they are positive phototaxis.

Phytoplankton distribution. Based on the value of the Evenness Index, it ranges from 0.49 to 0.93 . This value indicates that the distribution of the species in Limboto Lake varies. The results of the evenness index calculation are presented in Table 3. 
Table 3. Evenness Index in Limboto Lake

\begin{tabular}{lccc}
\hline \multirow{2}{*}{ Stations } & \multicolumn{3}{c}{ Evenness Index (E) } \\
\cline { 2 - 4 } & February & March & April \\
\hline Station 1 & 0.92 & 0.85 & 0.83 \\
Station 2 & 0.91 & 0.59 & 0.69 \\
Station 3 & 0.73 & 0.72 & 0.72 \\
Station 4 & 0.89 & 0.39 & 0.63 \\
Station 5 & 0.93 & 0.92 & 0.95 \\
Station 6 & 0.42 & 0.55 & 0.49 \\
\hline
\end{tabular}

Table 3 shows that spatially stations 1 and 5 have a very even distribution ( $>0.75$ ). station 2 , station 3, and station 4 are categorized as unstable distribution (0.50-0.75). Station 6 has an uneven distribution $(<0.50)$ as it is located in the middle of the lake, where floating cage net activity is irregular. Temporally, observations in February showed a very even distribution of phytoplankton (>0.75), while in March and April, the distribution was unstable (0.50-0.75). Haumahu (2005) states that environmental conditions and nutrient distribution influence phytoplankton distribution in rough waters. Zhou et al. (2011) stated that intensive floating cage net activities can accumulate nitrogen and phosphate in the bottom waters due to the remaining feed, which can increase water nutrients.

The Dominance Index shows the species richness in a community and the balance of the number of individuals of each species. The results of the calculation of the Dominance Index are presented in Table 4.

Table 4. Phytoplankton Dominance Index in Limboto Lake

\begin{tabular}{lccc}
\hline \multirow{2}{*}{ Stations } & \multicolumn{3}{c}{ Dominance Index (D) } \\
\cline { 2 - 4 } & February & March & April \\
\hline Station 1 & 0.059 & 0.091 & 0.089 \\
Station 2 & 0.064 & 0.366 & 0.206 \\
Station 3 & 0.232 & 0.150 & 0.130 \\
Station 4 & 0.084 & 0.571 & 0.212 \\
Station 5 & 0.111 & 0.09 & 0.065 \\
Station 6 & 0.555 & 0.403 & 0.337 \\
\hline
\end{tabular}

Table 4 shows the Dominance Index (D) value at the observation station ranging from 0.09 to 0.571 . This range indicates that, spatially and temporally, no phytoplankton species dominate the waters of Lake Limboto. The D value of station 6 is relatively high compared to other stations. Although Mycrocystis sp. found in relatively high numbers at this station, the index value, which is not close to 1 , indicates that there are no dominating species.

Setyobudiandi et al. (2009) explained that the dominance index value $<0.50$ means low and no organisms dominate. If the dominance value ranges from 0.75 to 1.00 , it means that it is high or there is a dominating organism. Also, Nugroho et al. (2012) stated that the greater the dominance index (D), the greater the tendency for certain species to dominate the waters. Conversely, the smaller the dominance index (D), the smaller the species that dominate.

Harmful and toxic algae. The results of the Dominance Index value (Table 4) indicate that there are no dominant phytoplankton species in Limboto Lake. Mycrocystis sp. has a relatively high abundance value among other species, with the highest value of 17,720 ind. $\mathrm{L}^{-1}$ in March. This species was only found in March and April at all stations (Table 5), with the highest abundance in March at station 5. Mycrocystis sp. is one of the harmful and toxic algal (Moreira et al., 2014; Mos, 2001). 
Blooming Mycrocystis sp. causes a drastic decrease in dissolved oxygen due to excessive utilization of oxygen to decompose dead organisms (Panjaitan, 2009). Suryanto \& Umi (2019) stated that Mycrocystis sp. able to adapt to polluted environmental conditions. Garno (2016) stated that eutrophication waters would eventually be dominated by particular phytoplankton types, which are generally inedible by aquatic fauna, especially zooplankton and fish, including as they are poisonous. The presence of the Mycrocystis sp. in waters indicates eutrophication. Samudra et al. (2013) stated that Mycrocystis sp. is phytoplankton, which can be used as an indicator of polluted waters as it is toxic. Other harmful and toxic algal species in Limboto Lake, even though in small numbers, are Peridinium sp. (Mos, 2001), Anabaena sp., and Pseudo-anabaena sp. (Moreira et al., 2014).

Table 5. Spatial-temporal distribution of harmful and toxic algae in Limboto Lake during research

\begin{tabular}{|c|c|c|c|c|c|c|c|c|c|c|c|c|c|c|c|c|c|c|c|}
\hline \multirow{2}{*}{ No } & \multirow{2}{*}{ Species } & \multicolumn{6}{|c|}{ February } & \multicolumn{6}{|c|}{ March } & \multicolumn{6}{|c|}{ April } \\
\hline & & 1 & 2 & 3 & 4 & 5 & 6 & 1 & 2 & 3 & 4 & 5 & 6 & 1 & 2 & 3 & 4 & 5 & 6 \\
\hline 1 & Mycrocystis sp. & $x$ & $x$ & $X$ & $x$ & $x$ & $x$ & $\sqrt{ }$ & $\sqrt{ }$ & $\sqrt{ }$ & $\sqrt{ }$ & $\sqrt{ }$ & $\sqrt{ }$ & $\sqrt{ }$ & $\sqrt{ }$ & $\sqrt{ }$ & $\sqrt{ }$ & $\sqrt{ }$ & $\sqrt{ }$ \\
\hline 2 & Anabaena sp. & $\sqrt{ }$ & $\sqrt{ }$ & $x$ & $\sqrt{ }$ & $\sqrt{ }$ & $x$ & $\sqrt{ }$ & $\sqrt{ }$ & $\sqrt{ }$ & $\sqrt{ }$ & $x$ & $\sqrt{ }$ & $x$ & $\sqrt{ }$ & $\sqrt{ }$ & $\sqrt{ }$ & $x$ & $\sqrt{ }$ \\
\hline 3 & Pseudo-anabaena sp. & $\sqrt{ }$ & $x$ & $x$ & $\sqrt{ }$ & $\sqrt{ }$ & $x$ & $\sqrt{ }$ & $\sqrt{ }$ & $\sqrt{ }$ & $x$ & $\sqrt{ }$ & $x$ & $\sqrt{ }$ & $\sqrt{ }$ & $\sqrt{ }$ & $x$ & $\sqrt{ }$ & $x$ \\
\hline 4 & Peridinium sp. & $x$ & $\sqrt{ }$ & $x$ & $x$ & $\sqrt{ }$ & $x$ & $\sqrt{ }$ & $\sqrt{ }$ & $\sqrt{ }$ & $\sqrt{ }$ & $x$ & $\sqrt{ }$ & $\sqrt{ }$ & $\sqrt{ }$ & $\sqrt{ }$ & $\sqrt{ }$ & $x$ & $\sqrt{ }$ \\
\hline
\end{tabular}

In many cases, the responding dominant species of phytoplankton are not toxic and beneficial until they exceed the assimilative capacity of the system, after which hypoxia and other adverse effects occur (suffocation of fish, direct toxic effects on fish and shellfish, the suffocation of fish from stimulation of gill mucus production, mechanical interference with filter-feeding by fish and bivalve mollusks, and deleterious effects on submerged grasses and benthic habitat organisms). When that threshold is reached, seemingly harmless species can have negative impacts (Ferreira et al., 2011).

Harmful algal blooms cause significant ecological and economic damage, such as impacts on wildlife, aquaculture, human health, and tourism (GEOHAB, 2006). Organic nutrients are essential in developing blooms of various harmful algal species, particularly cyanobacteria and dinoflagellates (Glibert et al., 2001). The high content of organic nitrogen relative to phosphorus suggests an excess of nitrogen during bloom conditions (Loza et al., 2013). The way to mitigate harmful algal bloom since phytoplanktons growth is limited primarily by nitrogen (Moreira et al., 2014).

\section{CONCLUSION}

There are 80 species from 7 divisions found in Limboto Lake during the observation. The thirty-five species belong to the Chlorophyta and Cyanophyta groups, the divisions with the largest number of individuals. Spatially, station 6 has the highest phytoplankton abundance $\left(20,894\right.$ ind. $\left.\mathrm{L}^{-1}\right)$, and station 5 is the lowest $\left(1,541\right.$ ind. $\left.\mathrm{L}^{-1}\right)$. Temporally, the lowest abundance occurred in February and increased in March and April. The harmful and toxic algal species found in Limboto Lake are Mycrocystis sp., Peridinium sp., Anabaena sp., and Pseudanabaena sp.

\section{REFERENCES}

Abadi, Y. P., Suharto, B., \& Widiatmono, J. B. R. (2014). Analysis of the waters of the klinter Nganjuk River based on biological parameters (plankton) [Indonesian]. Jurnal Sumberdaya Alam dan Lingkungan, 1(3), 36-42. https://jsal.ub.ac.id/index.php/jsal/article/view/141/126

Adjie, S., Samuel, S., \& Subagdja, S. (2017). Abundance and diversity of plankton in Arangarang Lake, Jambi [Indonesian]. Jurnal Penelitian Perikanan Indonesia, 9(7), 1-7. 
https://doi.org/10.15578/jppi.9.7.2003.1-7

Anderson, D. M., Burkholder, J. M., Cochlan, W. P., Glibert, P. M., Gobler, C. J., Heil, C. A., Kudela, R. M., Parsons, M. L., Rensel, J. E. J., Townsend, D. W., Trainer, V. L., \& Vargo, G. A. (2008). Harmful algal blooms and eutrophication: Examining linkages from selected coastal regions of the United States. Harmful Algae, 8(1), 39-53. https://doi.org/10.1016/j.hal.2008.08.017

Apridayanti, E. (2008). Evaluation of Water Environment Management in Lahor Reservoir, Malang Regency, East Java [Graduate thesis, Diponegoro University]. http://eprints.undip.ac.id/17305/1/EKA_APRIDAYANTI.pdf

Bergstrom, C., McKeel, C., \& Patel, S. (2007). Effects of pH on algal abundance: A model of Bay Harbor, Michigan. Deep Blue, 1-10. http://hdl.handle.net/2027.42/57443

Boyd, P. W., Rynearson, T. A., Armstrong, E. A., Fu, F., Hayashi, K., Hu, Z., Hutchins, D. A., Kudela, R. M., Litchman, E., Mulholland, M. R., Passow, U., Strzepek, R. F., Whittaker, K. A., Yu, E., \& Thomas, M. K. (2013). Marine phytoplankton temperature versus growth responses from polar to tropical waters-outcome of a scientific community-wide study. PLoS ONE, 8(5), e63091. https://doi.org/10.1371/journal.pone.0063091

Davis, C. C. (1955). The Marine and Fresh-Water Plankton. Michigan State University Press.

Ferreira, J. G., Andersen, J. H., Borja, A., Bricker, S. B., Camp, J., Cardoso da Silva, M., Garcés, E., Heiskanen, A. S., Humborg, C., Ignatiades, L., Lancelot, C., Menesguen, A., Tett, P., Hoepffner, N., \& Claussen, U. (2011). Overview of eutrophication indicators to assess environmental status within the European Marine Strategy Framework Directive. Estuarine, Coastal and Shelf Science, 93(2), 117-131. https://doi.org/10.1016/j.ecss.2011.03.014

Garno, Y. S. (2016). Eutrophication impact on community structure and evaluation of phytoplankton abundance determination methods [Indonesian]. Jurnal Teknologi Lingkungan, 13(1), 67-74. https://doi.org/10.29122/jtl.v13i1.1406

GEOHAB. (2006). Global ecology and oceanography of harmful algal blooms, harmful algal blooms in eutrophic systems. In Science. https://digital.csic.es/handle/10261/61546

Glibert, P. M., Magnien, R., Lomas, M. W., Alexander, J., Tan, C., Haramoto, E., Trice, M., \& Kana, T. M. (2001). Harmful algal blooms in the Chesapeake and coastal bays of Maryland, USA: Comparison of 1997, 1998, and 1999 events. Estuaries, 24(6), 875-883. https://doi.org/10.2307/1353178

Haas, A. F., Smith, J. E., Thompson, M., \& Deheyn, D. D. (2014). Effects of reduced dissolved oxygen concentrations on physiology and fluorescence of hermatypic corals and benthic algae. PeerJ, 2, e235. https://doi.org/10.7717/peerj.235

Haumahu, S. (2005). Spatial distribution of phytoplankton in Haria Saparua Bay Waters, Central Maluku [Indonesian]. IImu Kelautan - Indonesian Journal of Marine Sciences, 10(3), 126-134. https://doi.org/10.14710/ik.ijms.10.3.126-134

Koralay, N., Kara, O., \& Kezik, U. (2018). Effects of run-of-the-river hydropower plants on the surface water quality in the Solakli stream watershed, Northeastern Turkey. Water and Environment Journal, 32(3), 412-421. https://doi.org/10.1111/wej.12338

Ladja, J. D., Kasim, F., \& Kadim, M. K. (2020). Spatial analysis of Limboto Lake. Nikè, 8(1), 13-17. https://doi.org/https://doi.org/10.37905/.v8i1.4714

Lehmusluoto, P. (2000). Lake Toba, The first sound science initiative to abate change in the lake environment. Research and Monitoring for Basin Management Decisions, 1-12.

Loza, S., Moreira, A., Comas, A., Sánchez, M., Carmentate, M., \& Álamo, B. (2013). A phaeocystis bloom in the cuban archipelago. Harmful Algae News, 47, 20-21.

Lukman, Suryono, T., Chrismadha, T., Fakhrudin, M., \& Sudarso, J. (2008). Benthic biota community structure and its relation to sediment characteristics in Limboto Lake, Sulawesi [Indonesian]. Oseanologi dan Limnologi di Indonesia, 34(3), 479-494.

Moreira, A., Seisdedo, M., Muñoz, A., Comas, A., \& Alonso, C. (2014). Spatial and temporal distribution of phytoplankton as indicator of eutrophication status in the Cienfuegos Bay, Cuba. Revista de Gestão Costeira Integrada, 14(4), 597-609. https://doi.org/10.5894/rgci506

Mos, L. (2001). Domoic acid: A fascinating marine toxin. Environmental Toxicology and Pharmacology, 9(3), 79-85. https://doi.org/10.1016/S1382-6689(00)00065-X

Mustofa, A. (2015). Nitrate and phosphate contents as factors in the level of fertility in coastal 
waters [Indonesian]. Disprotek, 6(1), 13-19. https://ejournal.unisnu.ac.id/JDPT/article/view/193/328

Nugroho, K. D., Suryono, C. A., \& Irwani. (2012). Gastropod Community Structure in Coastal Waters, Genuk District, Semarang City [Indonesian]. Journal of Marine Research, 1(1), 100-109. https://doi.org/10.14710/jmr.v1i1.1996

Odum, E. P. (1998). Fundamental Ecology [Indonesian]: Translated from Fundamentals of Ecology. Translator: Samingan, T. Third Edition. In Universitas Gadjah Mada Press, Yogyakarta (Vol. 697).

Offem, B. O., Ayotunde, E., Ikpi, G. U., Ochang, S., \& Ada, F. B. (2013). Influence of seasons on water quality, abundance of fish and plankton species of Ikwori Lake, South-Eastern Nigeria. Fisheries and Aquaculture Journal, 2(1), 1-18. https://doi.org/10.4172/21503508.1000013

Panjaitan, P. (2009). Study on the Potential Pollution of PT. Aquafarm Nusantara floating net cages in Lake Toba's Aquatic Ecosystem [Indonesian]. Jurnal Visi, 17(3), 290-300.

Purnamaningtyas, S. E., \& Tjahjo, D. W. H. (2017). Observation of water quality to support fisheries in Cirata Reservoir, West Java [Indonesian]. Jurnal Penelitian Perikanan Indonesia, 14(2), 173-180. http://ejournalbalitbang.kkp.go.id/index.php/jppi/article/view/3642

Rahman, A., Pratiwi, N. T. M., \& Hariyadi, S. (2017). The structure of phytoplankton communities in Lake Toba, North Sumatera. Jurnal Ilmu Pertanian Indonesia, 21(2), 120127. https://doi.org/10.18343/jipi.21.2.120

Rice, E. W., Baird, R. B., Eaton, A. D., \& Lenore, S. (2012). Standard methods: For the examination of water and wastewater. American Public Health Association, American Water Works Association, Water Environmental Federation (22nd ed.). ISSN.

Sahami, F. M. (2006). Gastropod Community structure as bioindicator of organic pollution in Limboto Lake, Gorontalo Province [Indonesian]. Jurnal Ilmiah Agrobisnis Tropis (JIAT), 6(2), 65-70.

Samudra, S. R., Soeprobowati, T. R., \& Izzati, M. (2013). Composition, abundance and diversity of phytoplankton of Lake Rawa Pening Semarang Regency [Indonesian]. Bioma: Berkala IImiah Biologi, 15(1), 6-13. https://doi.org/10.14710/bioma.15.1.6-13

Sediadi, A. (2004). Upwelling effect on the abundance and distribution of phytoplankton in Banda Sea and surrounding waters [Indonesian]. MAKARA of Science Series, 8(2), 43-51. https://doi.org/10.7454/mss.v8i2.409

Setyobudiandi, I. (2009). Sampling and Data Analysis of Fisheries and Marine: Applied Sampling Methods in Coastal and Marine Areas [Indonesian]. MAKAIRA-FPIK IPB, Bogor.

Soeprobowati, T., \& Suedy, S. (2010). Rawapening Lake trophic status and the management solutions [Indonesian]. Jurnal Sains dan Matematika, 18(4), 158-169.

Sulastri, Harsono, E., Suryono, T., \& Ridwansyah, I. (2008). Relationship of land use, water quality and phytoplankton community of some small lakes in West Java. Oseanologi Dan Limnologi Di Indonesia, 34(2), 307-332.

Suryanto, A. M., \& Subarijanti, H. U. (2019). Estimation of trophic status using the phytoplankton and zooplankton abundance approaches in Sengguruh, Karangkates, Lahor, Wlingi Raya and Wonorejo Reservoir, East Java [Indonesian]. Jurnal I/miah Perikanan Dan Kelautan, 1(1), 7-13. https://doi.org/10.20473/jipk.v1i1.11692

Thoha, H. (2010). Abundance of plankton in Bangka-Belitung Waters and the South China Sea, Sumatra, May-June 2002 [Indonesian]. MAKARA of Science Series, 8(3), 96-102. https://doi.org/10.7454/mss.v8i3.452

Zhou, H. D., Jiang, C. L., Zhu, L. Q., Wang, X. W., Hu, X. Q., Cheng, J. Y., \& Xie, M. H. (2011). Impact of pond and fence aquaculture on reservoir environment. Water Science and Engineering, 4(1), 92-100. https://doi.org/10.3882/j.issn.1674-2370.2011.01.009 